\title{
Prevalence of undernutrition in elderly patients hospitalized in a geriatric unit in Belo Horizonte, MG, Brazil
}

\author{
Adriana K. Coelho, M.Sc. ${ }^{a}{ }^{\text {, }}$, Fabio L. Rocha, D.Sc. ${ }^{\mathrm{b}}$, and Maria A. Fausto, D.Sc. ${ }^{\mathrm{c}}$ \\ ${ }^{a}$ Geriatric Unit, Hospital do Instituto de Previdência dos Servidores do Estado de Minas Gerais, Belo Horizonte, Minas Gerais, Brazil \\ ${ }^{\mathrm{b}}$ Psychiatric Clinic, Hospital do Instituto de Previdência dos Servidores do Estado de Minas Gerais, Belo Horizonte, Minas Gerais, Brazil \\ ${ }^{\mathrm{c}}$ Food Department, School of Nutrition, Universidade Federal de Ouro Preto, Ouro Preto, Minas Gerais, Brazil
}

Manuscript received February 16, 2006; accepted July 3, 2006.

\begin{abstract}
Objectives: We evaluated, from anthropometric and biochemical indicators, the prevalence of undernutrition within an elderly population hospitalized in Belo Horizonte, Minas Gerais, Brazil, and identified social demographic, clinical and biochemical factors associated with undernutrition. Methods: A transverse sectional study involving 197 elderly patients was conducted. Anthropometric data were obtained from subjects directly or indirectly; clinical characteristics, including health problems, functional and cognitive abilities, and use of medication, were gathered from medical records; social demographic information was acquired by interviewing the subject or carer. Logistic regression analysis was employed to identify factors associated with undernutrition.

Results: According to the body mass index cutoff points recommended by the World Health Organization, $29.7 \%$ of subjects were classified as undernourished and $43.8 \%$ as eutrophic. Application of the Nutrition Screening Initiative system gave rise to an inverse situation in which 54.7\% of subjects were considered undernourished and only $29.2 \%$ were eutrophic. Statistical analysis of the studied variables showed that calf circumference $\leq 31 \mathrm{~cm}$ was significantly associated with undernutrition $(P<0.0001)$ irrespective of the classification system employed, and may thus be considered a strong marker for undernutrition. In contrast, total serum cholesterol level $\geq 4.14$ $\mathrm{mmol} / \mathrm{L}$ was identified as a protective factor against undernutrition $(P=0.01)$.

Conclusion: The prevalence of undernutrition among the hospitalized elderly in Brazil is very high. The measurement of calf circumference is a non-invasive and economical approach that can facilitate evaluation of the nutritional status of elderly individuals. (c) 2006 Elsevier Inc. All rights reserved.
\end{abstract}

Keywords: $\quad$ Hospitalized elderly population; Anthropometric evaluation; Indicators of undernutrition; Nutritional assessment; Calf circumference

\section{Introduction}

One of the most important clinical conditions that affect the elderly population is undernutrition. The main factors associated with nutritional disorders are multiple pathologies, poor oral health, problems with deglutition, pain, hypercatabolic status, and the use of medication [1]. Moreover, social isolation, poverty, and functional limitations often impose restrictions on the preparation and consumption of food. Moreover, within the elderly population, un-

* Corresponding author. Tel./fax: +55-31-3241-2922.

E-mail address: adrianakeller@terra.com.br (A.K. Coelho). dernutrition is generally associated with higher incidences of morbidity and mortality $[2,3]$.

It is estimated that by 2025 the elderly population of Brazil will exceed 30 million [4]. Despite this disturbing forecast, and its implications with respect to the provision of appropriate health care in the future, very little is currently known regarding the nutritional status of hospitalized elderly people. Thus, it is imperative to carry out studies involving this segment of the population to establish suitable monitoring and intervention procedures with the aim of improving the quality of life of the elderly.

The present study evaluated the prevalence of undernutrition among patients admitted to the Geriatric Unit of the 
Hospital do Instituto de Previdência dos Servidores do Estado de Minas Gerais (IPSEMG), Belo Horizonte, Minas Gerais, Brazil, and identified factors associated with undernutrition. To attain this objective, anthropometric and biochemical parameters in addition to the clinical, social and demographic histories of a group of elderly subjects were analyzed.

\section{Materials and methods}

Details of the project were presented to and approved by the ethical committee of the IPSEMG before commencement of the study. Appropriate informed consent was obtained in writing from each participant.

\section{Population studied}

The investigation involved 197 men and women $\geq 60$ y old who had been admitted to the hospital of the IPSEMG. The size of the sample population required to permit analysis at the $95 \%$ confidence level and with a precision of 5\% was based on the total number (372) of individuals admitted to the Geriatric Unit of the hospital during 2003 and, in the absence of precise information pertaining to geriatric patients in Brazil, on an incidence of undernutrition estimated to be $50 \%$.

\section{Data collection}

Data were collected from October 29, 2004 to March 28, 2005 by three trained nutritionists. Socioeconomic information, i.e., living arrangements, residential status, civil status, level of schooling and income, was acquired directly from the subjects or from their carers. Data concerning clinical aspects, including health problems, cognitive and physical conditions, and medicines administered, were obtained from the subjects and from their medical records.

With respect to health aspects, the organ and/or system affected was considered in the classification of pathologies and symptoms. Physical functions were evaluated by using the Katz Index of Activities of Daily Living [5], with subjects classified as being independent, partially dependent, or dependent. Cognitive abilities were assessed with the MiniMental State Examination [6], which provides a quantitative measurement of cognitive impairment, and the clock drawing [7] test, which is a simple and rapid qualitative method by which to detect cognitive disorders involving attention, language, orientation in time and space, and executive function deficits.

The diagnosis of mood disorders, including major depression, bipolar and dysthymic disorders, and non-specific depression, was based on the criteria adopted by the American Psychiatric Association [8]. Information concerning oral health was obtained directly from the subjects or from their medical records. The aspects investigated were pres- ence/absence of teeth, of dental prostheses (further classified, when present, as appropriate or inadequate), of caries, and of xerostomia. Medications received by subjects, as documented in the medical records, were grouped according to the Anatomical Therapeutic Chemical/Defined Daily Dose classification.

\section{Anthropometric evaluation}

Weight (kilograms) and height (meters) were measured using standard methods for subjects classified as functionally independent. For partially dependent subjects, stature was estimated from the knee height [9] and weight was calculated according to formulae proposed by Chumlea et al. [10]. Calf circumference was determined according to recommendations of the World Health Organization (WHO) [11]: a calf circumference $<31 \mathrm{~cm}$ was considered an indicator of undernutrition.

Body mass index (BMI) was calculated as weight (kilograms) divided by height (meters) squared. To establish a comparison between the elderly population of Brazil and those of other countries, the BMI cutoff points were based on the Nutrition Screening Initiative (NSI) [12] and the WHO [11] classification systems, i.e., underweight (BMI $<22$ and $<18.5 \mathrm{~kg} / \mathrm{m}^{2}$, respectively, for men and women), normal weight ( BMI 22-27 and 18.5-24.99 kg/m², respectively, for men and women), and overweight (BMI $>27$ and $>24.99 \mathrm{~kg} / \mathrm{m}^{2}$, respectively, for men and women).

\section{Biochemical evaluation}

Biochemical parameters, i.e., total serum cholesterol, serum albumin, and lymphocyte count, were obtained from medical records. The sample population was classified as follows: total serum cholesterol, normal (3.36-4.13 mmol/ $\mathrm{L})$, indicator of undernutrition $(<3.36 \mathrm{mmol} / \mathrm{L})$ [12]; serum albumin, eutrophic $(>35 \mathrm{~g} / \mathrm{L})$, slight undernutrition (28-35 $\mathrm{g} / \mathrm{L}$ ), moderate undernutrition $(21-27 \mathrm{~g} / \mathrm{L})$, and severe undernutrition $(<21 \mathrm{~g} / \mathrm{L})$ [13]; total lymphocytes, eutrophic $\left(>1800 / \mathrm{mm}^{3}\right)$, slight undernutrition $\left(1200-1800 / \mathrm{mm}^{3}\right)$, moderate undernutrition $\left(800-1199 / \mathrm{mm}^{3}\right)$, and severe undernutrition $\left(<800 / \mathrm{mm}^{3}\right)$ [14].

\section{Statistical analysis}

All statistical analyses were performed with Epi Info 2000 (Center for Disease Control and Prevention, Atlanta, GA, USA) and Stata 6.0 software (STATA Corporation, College Station, TX, USA), and differences were considered significant at $P<0.05$. Fisher's and chi-square tests were used to evaluate the distribution of category variables according to gender. The mean values of continuous variables with normal and asymmetric distributions were compared by application of Student's $t$ test and the MannWhitney non-parametric test, respectively. Factors 
Table 1

Social demographic parameters, distributed by gender, of the elderly population treated at the Geriatric Unit of the Hospital do Instituto de Previdência dos Servidores do Estado de Minas Gerais, Belo Horizonte, Minas Gerais, Brazil

\begin{tabular}{|c|c|c|c|c|c|c|c|}
\hline \multirow[t]{2}{*}{ Parameters } & \multicolumn{2}{|c|}{ Males } & \multicolumn{2}{|c|}{ Females } & \multicolumn{2}{|c|}{ Total } & \multirow[t]{2}{*}{$P$} \\
\hline & $n$ & $\%$ & $n$ & $\%$ & $n$ & $\%$ & \\
\hline \multicolumn{8}{|l|}{ Age (y) } \\
\hline$<75$ & 20 & 35.1 & 37 & 26.4 & 57 & 28.9 & \multirow[t]{2}{*}{0.224} \\
\hline$\geq 75$ & 37 & 64.9 & 103 & 73.6 & 140 & 71.1 & \\
\hline \multicolumn{8}{|l|}{ Living arrangements } \\
\hline With family & 52 & 91.2 & 123 & 88.5 & 175 & 89.3 & \multirow[t]{3}{*}{0.919} \\
\hline Alone & 4 & 7.0 & 12 & 8.6 & 16 & 8.2 & \\
\hline In an institution & 1 & 1.8 & 4 & 2.9 & 5 & 2.6 & \\
\hline \multicolumn{8}{|l|}{ Residential status } \\
\hline Owner occupier & 50 & 89.3 & 117 & 84.2 & 167 & 85.6 & \multirow[t]{3}{*}{0.728} \\
\hline Rented & 4 & 7.1 & 16 & 11.5 & 20 & 10.3 & \\
\hline Other & 2 & 3.6 & 6 & 4.3 & 8 & 4.1 & \\
\hline \multicolumn{8}{|l|}{ Civil status } \\
\hline Married & 39 & 68.4 & 23 & 16.5 & 62 & 31.6 & \multirow[t]{3}{*}{$<0.0001$} \\
\hline Single & 6 & 10.5 & 28 & 20.1 & 34 & 17.3 & \\
\hline Widow & 12 & 21.1 & 88 & 63.3 & 100 & 51.0 & \\
\hline \multicolumn{8}{|l|}{ Schooling (y) } \\
\hline$\leq 4$ & 36 & 64.3 & 85 & 63.0 & 121 & 63.4 & \multirow[t]{3}{*}{0.874} \\
\hline $4-11$ & 11 & 19.6 & 24 & 17.8 & 35 & 18.3 & \\
\hline$\geq 11$ & 9 & 16.1 & 26 & 19.3 & 35 & 18.3 & \\
\hline \multicolumn{8}{|l|}{ Physical functions } \\
\hline Independent & 23 & 41.1 & 53 & 37.9 & 76 & 45.8 & \multirow[t]{3}{*}{0.914} \\
\hline Partially dependent & 12 & 21.4 & 31 & 22.1 & 43 & 25.9 & \\
\hline Dependent & 21 & 37.5 & 56 & 40.0 & 47 & 28.3 & \\
\hline \multicolumn{8}{|l|}{ Cognitive abilities } \\
\hline Unimpaired & 17 & 30.9 & 51 & 39.5 & 68 & 37.0 & \multirow[t]{2}{*}{0.267} \\
\hline Impaired & 38 & 69.1 & 78 & 60.5 & 116 & 63.0 & \\
\hline \multicolumn{8}{|l|}{ Depression } \\
\hline Absent & 35 & 61.4 & 81 & 58.7 & 116 & 59.5 & \multirow[t]{2}{*}{0.726} \\
\hline Present & 22 & 38.6 & 57 & 41.3 & 79 & 40.5 & \\
\hline \multicolumn{8}{|l|}{ Edentulous } \\
\hline No & 30 & 65.2 & 69 & 72.6 & 99 & 70.2 & \multirow[b]{2}{*}{0.367} \\
\hline Yes & 16 & 34.8 & 26 & 27.4 & 42 & 29.8 & \\
\hline Presence of dental pros & & & & & & & \\
\hline No & 19 & 41.3 & 35 & 36.8 & 54 & 38.3 & \\
\hline Yes and appropriate & 17 & 37.0 & 44 & 46.3 & 61 & 43.3 & 0.551 \\
\hline Yes but inadequate & 10 & 21.7 & 16 & 16.8 & 26 & 18.3 & \\
\hline Presence of caries & & & & & & & \\
\hline No & 42 & 91.3 & 89 & 93.7 & 131 & 92.9 & \\
\hline Yes & 4 & 8.7 & 6 & 6.3 & 10 & 7.1 & 0.728 \\
\hline Xerostomia (dry mouth) & & & & & & & \\
\hline Absent & 31 & 67.4 & 67 & 70.5 & 98 & 69.5 & \\
\hline Present & 15 & 32.6 & 28 & 29.5 & 43 & 30.5 & 0.705 \\
\hline
\end{tabular}

associated with undernutrition were analyzed using a logistic regression model [15].

\section{Results}

The sample population consisted of 197 elderly individuals consisting of 57 men (28.9\%) and 140 women (71.1\%). The men's average age was $79.3 \pm 8.74$ y (range, 63.6$100.2 \mathrm{y})$ and the women's average age was $81.0 \pm 8.36 \mathrm{y}$ (range, 63.5-98.3 y). Of the total group, $71.1 \%$ were $>75 \mathrm{y}$.

Table 1 lists the social, demographic, and clinical characteristics of the sample population distributed according to gender. There was a significant difference $(P<0.0001)$ between men and women regarding civil status: most men $(68.4 \%)$ were married, whereas most women were widows. Most individuals lived in their own houses with their families. The major proportion (63.4\%) of the population had attended school for a maximum of only $4 \mathrm{y}$. The distributions of physical function, cognitive abilities, and incidence of depression were very similar for men and women within the population: $>50 \%$ of the subjects presented some degree of physical or cognitive limitation, and depression affected $\sim 40.5 \%$ of individuals. Regarding oral health, the sample population suffered mainly from a lack of teeth and from xerostomia ( $29.8 \%$ and $30.5 \%$, respectively). 
Table 2

Anthropometric data, distributed by gender, of the elderly population treated at the Geriatric Unit of the Hospital do Instituto de Previdência dos Servidores do Estado de Minas Gerais, Belo Horizonte, Minas Gerais, Brazil

\begin{tabular}{lcccccc}
\hline Parameters & \multicolumn{2}{l}{ Men } & & \multicolumn{2}{l}{ Women } & \multirow{2}{*}{$P$} \\
\cline { 2 - 3 } & $n$ & Mean $\pm \mathrm{SD}$ & & $n$ & Mean $\pm \mathrm{SD}$ & \\
\hline Weight $(\mathrm{kg})$ & 55 & $54.88 \pm 13.58$ & & 137 & $50.77 \pm 16.08$ & 0.10 \\
Stature $(\mathrm{m})$ & 57 & $1.63 \pm 0.08$ & & 139 & $1.49 \pm 0.08$ & $<0.0001$ \\
BMI $\left(\mathrm{kg} / \mathrm{m}^{2}\right)$ & 55 & $20.51 \pm 4.23$ & & 137 & $22.60 \pm 6.55$ & 0.03 \\
CC $(\mathrm{cm})$ & 56 & $30.48 \pm 3.82$ & & 138 & $30.41 \pm 5.71$ & 0.93
\end{tabular}

BMI, body mass index; CC, calf circumference

The most frequent medications used by the studied individuals were analgesic (94.4\%), antispasmodic (87.3\%), antithrombotic $(69.0 \%)$, antiulcer $(51.8 \%)$, and antibiotic $(43.7 \%)$ agents, angiotensin-converting enzyme inhibitors (36.5\%), and diuretic (24.9\%), antiasthmatic (20.3\%), antipsychotic (19.3\%), antidepressive (15.7\%), and antiepileptic $(15.8 \%)$ agents. The most common illnesses were related to the vascular and cardiovascular (68.5\%), digestive $(41.6 \%)$, genitourinary $(37.6 \%)$, respiratory $(31.0 \%)$, and endocrine $(24.9 \%)$ systems, mental and behavioral disorders
(22.3\%), gastrointestinal problems (18.8\%), dementia $(17.3 \%)$, sensory loss $(14.7 \%)$, ophthalmic problems (14.2\%), and fractures (14.2\%).

The anthropometric data presented in Table 2 showed that, although male subjects were significantly taller than female subjects $(P<0.0001)$, there were no gender-related differences with respect to body weight and, hence, the mean BMI value was significantly higher $(P=0.03)$ for women than for men. When BMI values were classified according to WHO recommendations [11], the distributions within the male and female groups were similar, and $43.8 \%$ of the total population ( $45.5 \%$ of men and $43.1 \%$ of women) were categorized as eutrophic (Table 3). According to the NSI classification [12]; however, the total percentage of eutrophic subjects was much smaller at only $29.2 \%(27.3 \%$ of men and $29.9 \%$ of women), although the distributions within the male and female groups were similar. Approximately $57 \%$ of the total sample population presented calf circumferences $\leq 31 \mathrm{~cm}$, and the male and female groups exhibited similar distributions (Table 3). The biochemical data showed a high incidence of undernutrition within the elderly population: the prevalence was $46.1 \%$ according to total serum cholesterol levels, $75.6 \%$ according to serum

Table 3

Anthropometric data and biochemical parameters, distributed by gender, of the elderly population treated at the Geriatric Unit of the Hospital do Instituto de Previdência dos Servidores do Estado de Minas Gerais, Belo Horizonte, Minas Gerais, Brazil

\begin{tabular}{|c|c|c|c|c|c|c|c|}
\hline \multirow[t]{2}{*}{ Parameters } & \multicolumn{2}{|c|}{ Men } & \multicolumn{2}{|c|}{ Women } & \multicolumn{2}{|c|}{ Total } & \multirow[t]{2}{*}{$P$} \\
\hline & $n$ & $\%$ & $n$ & $\%$ & $n$ & $\%$ & \\
\hline \multicolumn{8}{|c|}{ BMI (WHO) $\left(\mathrm{kg} / \mathrm{m}^{2}\right)$} \\
\hline$\leq 18.49$ & 20 & 36.4 & 37 & 27.0 & 57 & 29.7 & \\
\hline $18.5-24.99$ & 25 & 45.5 & 59 & 43.1 & 84 & 43.8 & \\
\hline$\geq 25.0$ & 10 & 18.1 & 41 & 29.9 & 51 & 26.5 & \\
\hline Total & 55 & 100.0 & 137 & 100.0 & 192 & 100.0 & 0.20 \\
\hline \multicolumn{8}{|c|}{ BMI (NSI) (kg/m²) } \\
\hline$<22$ & 36 & 65.4 & 69 & 50.4 & 105 & 54.7 & \\
\hline $22-27$ & 15 & 27.3 & 41 & 29.9 & 56 & 29.2 & \\
\hline$>27$ & 4 & 7.3 & 27 & 19.7 & 31 & 16.1 & \\
\hline Total & 55 & 100.0 & 137 & 100.0 & 192 & 100.0 & 0.06 \\
\hline \multicolumn{8}{|c|}{ Calf circumference $(\mathrm{cm})$} \\
\hline$>31$ & 24 & 42.9 & 59 & 42.8 & 83 & 42.8 & \\
\hline$\leq 31$ & 32 & 57.1 & 79 & 57.2 & 111 & 57.2 & 0.99 \\
\hline \multicolumn{8}{|c|}{ Serum albumin $(\mathrm{g} / \mathrm{L})$} \\
\hline $35-50$ & 14 & 24.6 & 34 & 24.5 & 48 & 24.5 & 0.323 \\
\hline $28-35$ & 23 & 40.4 & 71 & 51.1 & 94 & 48.0 & \\
\hline $21-27$ & 16 & 28.1 & 30 & 21.6 & 46 & 23.5 & \\
\hline$<21$ & 4 & 7.0 & 4 & 2.9 & 8 & 4.1 & \\
\hline \multicolumn{8}{|c|}{ Lymphocyte count $\left(\mathrm{mm}^{-3}\right)$} \\
\hline$>1800$ & 17 & 29.8 & 40 & 28.6 & 57 & 28.9 & 0.99 \\
\hline $1200-1800$ & 19 & 33.3 & 47 & 33.6 & 66 & 33.5 & \\
\hline 800-1199 & 12 & 21.0 & 29 & 20.7 & 41 & 20.8 & \\
\hline$<800$ & 9 & 15.8 & 24 & 17.1 & 33 & 16.8 & \\
\hline \multicolumn{8}{|c|}{ Total serum cholesterol (mmol/L) } \\
\hline$<3.36$ & 23 & 41.1 & 26 & 19.0 & 49 & 25.4 & $<0.0001$ \\
\hline $3.36-4.13$ & 17 & 30.4 & 23 & 16.8 & 40 & 20.7 & \\
\hline$\geq 4.14$ & 16 & 28.6 & 88 & 64.2 & 104 & 53.9 & \\
\hline
\end{tabular}

BMI (NSI), body mass index cutoff points recommended by the Nutrition Screening Initiative [12]; BMI (WHO), body mass index cutoff points recommended by the World Health Organization [11] 
Table 4

Relation between social demographic, clinical and biochemical parameters and undernutrition (according to WHO and NSI classifications) as revealed by multivariate and logistic regression analysis

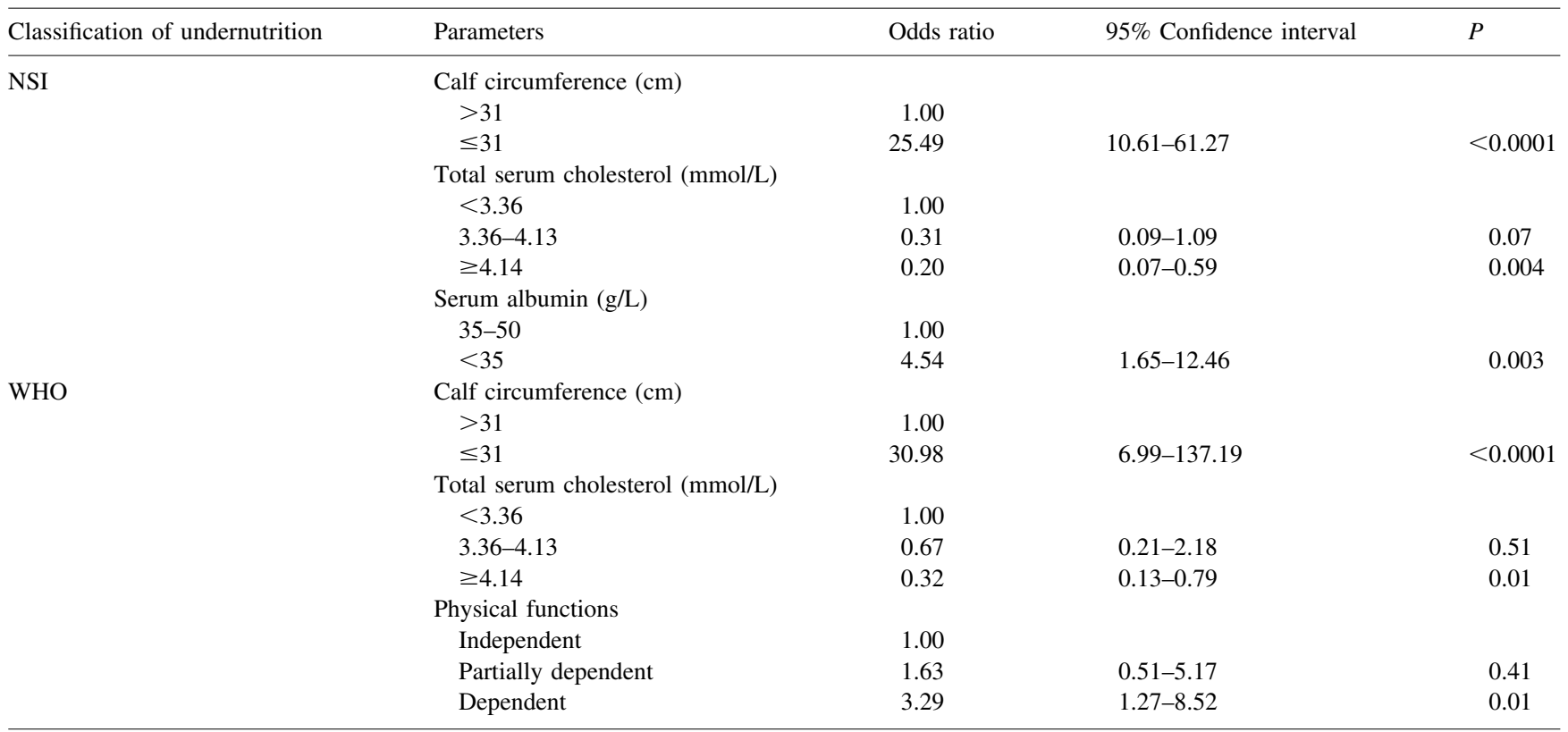

NSI, Nutrition Screening Initiative; WHO, World Health Organization

albumin levels, and $71.1 \%$ according to lymphocyte count (Table 3).

Univariate logistic regression analysis suggested that the factors positively associated with undernutrition according to the NSI classification were age $\geq 75 \mathrm{y}$ (odds ratio [OR], 2.06; 95\% confidence interval [CI], 1.10-3.87), lack of teeth (OR, 5.46; 95\% CI, 2.28-13.1), partial physical dependence (OR, 2.28; 95\% CI, 1.01-4.93), physical dependence (OR, 4.54; 95\% CI, 2.27-9.01), cognitive impairment (OR, 2.18; 95\% CI, 1.18-4.04), calf circumference $\leq 31 \mathrm{~cm}$ (OR, 22.1; 95\% CI, 10.38-46.99), and serum albumin level $<35 \mathrm{~g} / \mathrm{L}$ (OR, 4.05; 95\% CI, 1.99-8.24). The protective factors were appropriate dental prosthesis (OR, 0.35; 95\% CI, 0.16-0.76), inadequate dental prosthesis (OR, 0.33; 95\% CI, 0.12-0.86), and total serum cholesterol level $\geq 3.36 \mathrm{mmol} / \mathrm{L}$ (OR, $0.21 ; 95 \% \mathrm{CI}, 0.09-0.46)$. The final statistical model (Table 4) indicated that the factors positively associated with undernutrition (NSI definition) were calf circumference $\leq 31 \mathrm{~cm}$ (OR, 25.49; 95\% CI, 10.6161.27 ) and serum albumin level $<35 \mathrm{~g} / \mathrm{L}$ (OR, 4.54; 95\% CI, 1.65-12.46). Total serum cholesterol level $\geq 4.14$ $\mathrm{mmol} / \mathrm{L}$ was identified as a protective factor against undernutrition (OR, 0.20; 95\% CI, 0.07-0.59).

Univariate logistic regression analysis suggested that the factors positively associated with undernutrition according to the WHO classification were age $\geq 75$ y (OR, 2.16 ; 95\% CI, 1.02-4.57), lack of teeth (OR, 3.41; 95\% CI, 1.56-7.44), physical dependence (OR, 7.16; 95\% CI, 3.19-16.10), cognitive impairment (OR, 2.75; 95\% CI, $1.32-5.72)$, calf circumference $\leq 31 \mathrm{~cm}(\mathrm{OR}, 42.3 ; 95 \%$ CI, 9.89-180.97), and serum albumin level $<35 \mathrm{~g} / \mathrm{L}$
(OR, 3.75; 95\% CI, 1.49-9.42). The single protective factor was a total serum cholesterol level $\geq 4.14 \mathrm{mmol} / \mathrm{L}$ (OR, $0.25 ; 95 \%$ CI, 0.12-0.52). The final statistical model (Table 4) indicated that the factors positively associated with undernutrition (WHO definition) were calf circumference $\leq 31 \mathrm{~cm}(\mathrm{OR}, 30.98$; 95\% CI, 6.99137.19) and physical dependence (OR, 3.29; 95\% CI, 1.27-8.52). A total serum cholesterol level $\geq 4.14$ $\mathrm{mmol} / \mathrm{L}$ remained the single protective factor against undernutrition (OR, 0.32; 95\% CI, 0.13-0.79).

\section{Discussion}

Considering the BMI cutoff points recommended by WHO [11], the incidence of undernutrition among subjects was $29.7 \%$, and $43.8 \%$ were classified as eutrophic. In contrast, according to NSI [12] recommendations, the frequencies of undernutrition and eutrophia were $54.7 \%$ and $29.2 \%$, respectively. The latter data are in agreement with values recently reported from other countries, especially Spain, and show a general high frequency of undernutrition within hospitalized elderly populations [16-20]. With respect to the apparent disparity between the WHO and NSI indicators of undernutrition, it is important to point out that the former is not specific for the elderly population because the cutoff points were derived from the extrapolation of data obtained from younger individuals. Thus, although the WHO classification adopts similar cutoff points for young and old adults, the NSI cutoff points relate specifically to older individuals. 
Information relating to the nutritional status of the elderly hospitalized population of Brazil is scarce. However, a multicenter study employing the Avaliação Nutricional Subjetiva Global (ANSG) classification reported a prevalence of $52.8 \%$ for undernutrition in a sample population of 1440 hospitalized elderly [21,22]. In another study involving hospitalized elderly women, undernutrition was estimated to be $70 \%$ and $65 \%$, respectively, according to the ANSG and WHO classifications [23].

Some researchers have suggested that the determination of calf circumference represents a reliable method of assessing muscle mass in the elderly [24-26], and it has been argued that this parameter provides a more sensitive measurement than upper arm circumference [11]. In the present study, $57.2 \%$ of individuals presented calf circumferences $\leq 31 \mathrm{~cm}$.

With respect to biochemical parameters, high frequencies of hypoalbuminemia (75.5\%), lymphopenia (71.1\%), and hypocholesterolemia (46.1\%) were established within the elderly population studied. High incidences of hypoalbuminemia and lymphopenia have previously been recorded in elderly hospitalized subjects $[16,18,19,27]$. Several authorities [28-31] consider that hypocholesterolemia may be associated with an increased risk of morbidity/ mortality within the elderly population because cholesterol levels $<4.14 \mathrm{mmol} / \mathrm{L}$ could indicate a decrease in the amount of lipoprotein and visceral protein.

Irrespective of the BMI classification adopted, a calf circumference $\leq 31 \mathrm{~cm}$ was identified as an indicator of undernutrition, whereas a total cholesterol level $\geq 4.14$ $\mathrm{mmol} / \mathrm{L}$ appeared as a protective factor. A serum albumin level $<35 \mathrm{~g} / \mathrm{L}$ emerged as an indicator of undernutrition when the NSI classification was used, although this result was not unexpected because hypoalbuminemia is a marker for the diagnosis of undernutrition in clinical practice. Further, functional dependence became a strong indicator of undernutrition when the WHO classification was employed, but this result was also expected because the BMI cutoff point of $18.5 \mathrm{~kg} / \mathrm{m}^{2}$ selects for fragile elderly people exhibiting some degree of functional dependence.

Although the use of calf circumference measurement as a reliable method of evaluating the nutritional status of elderly individuals has often been suggested, this is the first report that attempts to establish an association between calf circumferences $\leq 31 \mathrm{~cm}$ and undernutrition within an elderly hospitalized population. Such an approach is particularly relevant in clinical practice because it is non-invasive, cheap, and rapid, and the measurement can be readily obtained, particularly for hospitalized patients who require regular monitoring. The implementation of this method by institutions involved in the care of geriatric patients could contribute to the improvement of the support given to the elderly.

\section{Acknowledgments}

The authors thank Letícia Clark Peres and Sylvana Marques Morais for helpful collaboration during the collection of the data.

\section{References}

[1] Omran ML, Morley JE. Assessment of protein energy malnutrition in older persons, part I: history, examination, body composition and screening tolls. Nutrition 2000;16:50-63.

[2] Rikkert MGO, Rigaud A. Malnutrition research: high time to change the menu. Age Aging 2003;32:241-3.

[3] Junqueira JCS, Soares EC, Filho HRC, Hoehr NF, Magro DO, Ueno M. Nutritional risk factors for postoperative complications in Brazilian elderly patients undergoing major elective surgery. Nutrition 2003;194:321-32.

[4] Veras RP, Coutinho E, Ney JRG. População idosa no Rio de Janeiro (Brasil): estudo-piloto da confiabilidade e validação do segmento de saúde mental do questionário BOAS. Rev Saude Publica 1990;24: $156-63$.

[5] Lewis C, Bottolomley JM. Assessment instruments. Geriatric physical therapy: a clinical approach. 2nd ed. Norwalk: Appleton \& Lange; 1994, p. 139-86.

[6] Folstein MF, Folstein SE, Hugh MC. Mini-mental state. J Psychiatr Res 1985;12:189-98.

[7] Shulman KL. Clock drawing: is it an ideal cognitive screening test? Int J Geriatr Psychiatry 2000;15:548-61.

[8] Diagnostic and statistical manual of mental disorders. 4th ed. Washington, DC: American Psychiatric Association; 1994, p. 317-91.

[9] Chumlea WC, Roche AF, Steinbaugh ML. Estimating stature from knee height for persons 60 to 90 years of age. J Am Geriatr Soc 1985;33:116-9.

[10] Chumlea WC, Roche AF, Steinbaugh ML. Anthropometric approaches to the nutritional assessment of the elderly. In: Munro $\mathrm{H}$, Danford DE, editors. Human nutrition: nutrition, aging, and the elderly. New York: Plenum Press; 1989, p. 335-61.

[11] Physical status: the use and interpretation of anthropometry. World Health Organization Technical Report Series 854. Geneva: World Health Organization; 1995.

[12] Nutrition interventions manual for professionals caring for older Americans. Washington, DC: Nutrition Screening Initiative; 1992.

[13] Shronts EP. El proceso de evaluación nutricional en los Estados Unidos. Lect Nutr 1997;4:40-55.

[14] Kuczmarski MF, Kuczmarski RJ. Evaluación nutricional de los adultos de edad avanzada. In: Schlenker E, editor. Nutrición en el envejecimiento. 2nd ed. Madrid: Mosby/Doyma; 1994, p. 259-87.

[15] Hosmer DW, Lemeshow S. Applied logistic regression. New York: John Wiley; 2000.

[16] Asensio A, Ramos A, Nunes S. Prognostic factors of mortality related to nutritional and functional status in the hospitalized elderly. Med Clin 2004;123:370-3.

[17] Olmos MAM, Vasquez MJM, Sierra AL, Gorriria MJM, Bouzon SC, Nunez IC, et al. Detección del riesgo de malnutrición en ancianos hospitalizados. Nutr Hosp 2002;17:22-7.

[18] Mias C, Jürschik P, Masón T, Sadurni M, Aguila JJ, Sola R, et al. Evaluación del estado nutricional de los pacientes mayores atendidos en una unidad de hospitalización a domicilio. Nutr Hosp 2003;18:6-14.

[19] Martinez AR, Vegas AA, Palomo SN, Santos IM. Prevalence and risk factors associated to malnutrition in elderly inpatients. Ann Med Interne (Paris) 2004;21(6):263-8.

[20] Ramos MJG, Valverde MGC. Alta prevalencia de la desnutrición en españoles ingresados em um hospital general y factores asociados. Arch Latinoam Nutr 2005;55:71-5. 
[21] Correia MITD, Caiaffa WT, Waitzberg DL. Inquérito brasileiro de avaliação nutricional hospitalar-IBRANUTRI. Rev Bras Nutr Clin 1998;13:30-40.

[22] Waitzberg DL, Caiaffa WT, Correia MI. Hospital malnutrition: the Brazilian national survey: a study of 4000 patients. Nutrition 2001;17: 573-80.

[23] Cordeiro RG, Moreira EAM. Avaliação nutricional do idoso hospitalizado. Rev Bras Nutr Clin 2003;18:106-12.

[24] Chumlea WMC, Guo SS, Vellas B. Techniques of assessing muscle mass and function (sarcopenia) for epidemiological of the elderly. J Gerontol A Biol Med Sci 1995;50A:45-51.

[25] Baumgartner RN, Koehler KM, Gallagher D. Epidemiology of sarcopenia among the elderly in New Mexico. Am J Epidemiol 1998;147:755-63.

[26] Rolland Y, Cances-Lauwers V, Cournot M, Nourhashémi F, Reynish W, Rivière D, et al. Sarcopenia, calf circumference, and physical function of elderly women: a cross-sectional study. J Am Geriatr Soc 2003;51:1120-4.

[27] Lansey S, Waslien C, Mulvihill M, Fillit H. The role of anthropometry in the assessment of malnutrition in the hospitalized frail elderly. Gerontology 1993;39:346-53.

[28] Rudman D, Mattson DE, Nagraj HS. Prognostic significance of serum cholesterol in nursing home men. JPEN 1988;12:155-8.

[29] Noel MA, Smith TK, Ettinger WH. Characteristics and outcomes of hospitalized older patients who develop hypocholesterolemia. J Am Geriatr Soc 1991;39:455-61.

[30] Forette B, Tortrat D, Wolmark Y. Cholesterol as a risk factor for mortality in elderly women. Lancet 1989;1:868-70.

[31] Brescianini S, Maggi S, Farchi G, Mariotti MS, Dicarlo A, Baldereschi $\mathrm{M}$, et al. Low total cholesterol and increased risk of dying: Are low levels clinical warning signs in the elderly? Results from the Italian longitudinal study on aging. J Am Geriatr Soc 2003;51:991-6. 